\title{
PENGARUH KOMPETENSI TERHADAP PRESTASI KERJA KARYAWAN BAGIAN MARKETING PADA KOPERASI SERBA USAHA (KSU) SINAR JAYA MALANG
}

\author{
Muhammad Budi Arifin \\ Department of Management FEB UMM \\ E-mail: arief.budi666@gmail.com
}

\begin{abstract}
The purpose of this study was to determine the effect of competence on the part of employes job performance marketing division. This type of research is a quantitative study conducted on 32 employees of the marketing Koperasi Serba Usaha (KSU) Sinar Jaya Malang. Analysis tools used were a range of scales and multiple linear regression analysis. The results of research competence influence on employee performance, including the ability to know that the competence evidenced in the high category with an average score scale range is 100.67, competence knowledge in very high category with a score of 105, and competence in the category of self-concept is also very high with the average score scale range is 109.67. Employee performance in the high category, indicated by an average score of 93.33 scale range.
\end{abstract}

Keywords: The Characteristics of Individuals, Competence and employee performance, Marketing.

\section{PENDAHULUAN}

Koperasi merupakan usaha bersama yang berbadan hukum, anggota ialah pemilik dan menggunakan jasanya dan mengembalikan semua penerimaan diatas biayanya kepada anggota sesuai dengan transaksi yang mereka jalankan. koperasi merupakan suatu perkumpulan yang beranggotakan orang-orang atau badan-badan yang berkerjasama secara kekeluargaan dalam menjalankan usahanya, untuk mempertinggi kesejahteraan anggotanya. Dalam menjalankan tugasnya koperasi dituntut untuk meningkatkan kualitas kerja dan kuantitas pelayanan kerjanya agar dapat bersaing dengan koperasi lain untuk mencapai tujuan perusahaan. Kompetensi adalah karakteristik yang mendasari seseorang dan berkaitan dengan efektifitas kinerja individu dalam pekerjaanya (Spencer \& Spencer, 1993). Dari pengertian diatas kompetensi individu merupakan sesuatu yang melekat dalam dirinya yang dapat digunakan untuk memprediksi tingkat prestasi kerja karyawan. Sesuatu yang dimaksud yaitu karakteristik kompetensi yang menyangkut motif, karakter pribadi, konsep diri, pengetahuan dan perilaku. Karakterisitik kompetensi tersebut dapat meramalkan suatu perilaku tertentu yang pada akhirnya akan muncul sebagai prestasi kerja. 
Kompetensi juga selalu melibatkan intensi (kesengajaan) yang mendorong sejumlah motif atau karakter pribadi untuk melakukan suatu aksi menuju terbentuknya suatu hasil.

Mangkunegara(2001:67),

mengatakan prestasi kerja adalah hasil kerja secara kualitas, kuantitas dan ketepatan waktu yang dicapai seorang karyawan dalam melaksanakan tugasnya sesuai dengan tanggung jawab yang diberikan kepadanya. Berdasarkan pendapat di atas maka dapat disimpulkan bahwa prestasi kerja adalah sebagai hasil kerja yang telah dicapai seseorang dari tingkah laku kerjanya dalam melakukan aktivitas kerja. Informasi tentang tinggi rendahnya prestasi kerja seorang karyawan di dapat melalui proses penilaian yang disebut performance appraisal.

Koperasi Serba Usaha (KSU)

SINAR JAYA adalah lembaga pembiayaan di bidang keuangan, Jumlah karyawan yang dimiliki adalah sebanyak 38 orang pegawai, yang terbagi menjadi 6 orang pegawai sebagai pengurus yang bertugas didalam kantor, sedangkan 32 orang merupakan karyawan bagian pemasaran (sales marketing) yang mempunyai tugas untuk mencari anggota. Cara kerja para pegawai koperasi serba usaha (KSU) SINAR JAYA Malang yaitu mencari anggota secara individu, menawarkan produk jasa keuangan koperasi serba usaha (KSU) SINAR JAYA dan ada anggota yang datang sendiri kekantor mengajukan permohonan kredit pembiayaan.

Dalam rangka operasional, kompetensi sales marketing yaitu berkaitan dengan kemampuan intelektual dan berkomunikasi, untuk dapat mempengaruhi calon anggota supaya dapat bergabung dalam koperasi serba usaha (KSU) SINAR JAYA Malang. Dalam rumusan kompetensi karyawan bagian pemasaran Koperasi Sinar Jaya Malang ini digunakan model dan kategori kompetensi, yaitu: sikap dan nilai-nilai (self concept): mencakup kesadaran tentang etika dan hukum, kesadaran untuk menghargai diri sendiri, kepekaan pemasaran. Pengetahuan (knowledge): mencakup teori dan prinsip pemasaran, pengetahuan visi dan misi perusahaan, pengetahuan umum, dan pengetahuan khusus. Kemampuan (skills): mencakup kemampuan bekerja sama, keterampilan menjual jasa, keterampilan berkomunikasi.

Pencapaian kinerja pada Koperasi Serba Usaha (KSU) SINAR JAYA Malang membutuhkan konsistensi dan kualitas karyawan bagian pemasaran (marketing), untuk mencapai tujuan bersama yang ingin diwujudkan oleh organisasi. Oleh karena itu diperlukan karyawan pemasaran yang mempunyai prestasi kerja yang tinggi. Prestasi kerja yang diraih oleh karyawan bagian pemasaran belum bisa dikatakan baik hal ini ditunjukkan dengan banyaknya karyawan yang belum bisa mencapai target yang di tentukan perusahaan.

Dari 32 jumlah karyawan bagian pemasaran, yang dapat memenuhi target perusahaan secara terus menerus dalam empat bulan terakhir dari bulan januari sampai maret hanya terdapat 9 karyawan. Untuk 23 karyawan lainya belum dapat merealisasikan target yang ditentukan perusahaan yaitu 
menyalurkan dana pinjaman kepada anggota sebanyak 30 juta/bulan. Hal ini menunjukkan bahwa prestasi kerja karyawan pada bagian pemasaran belum bisa di katakan baik, prestasi kerja pegawai juga didukung dengan kompetensi pegawai di bagian pemasaran dalam mencari anggota baru. Hal tersebut menunjukkan bahwa kompetensi karyawan sangat berpengaruh terhadap prestasi kerja karyawan.

Prestasi kerja karyawan yang berbeda dalam perusahaan yang ditunjukkan dengan adanya perbedaan jumlah nasabah yang diperoleh, besarnya jumlah modal yang mampu dipinjamkan, tingkat ketepatan waktu dalam menyelesaikan pekerjaan merupakan masalah yang perlu dikaji lebih lanjut.

Perbedaaan prestasi kerja dan penyebab ini perlu diperhatikan oleh manajer agar kedepanya mampu membuat solusi dari permasalahan sehingga jika ada karyawan yang berprestasi rendah pada kemudian hari ada motivasi untuk meningkatkan prestasi kerjanya, dari kondisi ini maka prestasi perusahaanpun akan mampu ditingkatkan. Seperti yang ditulis oleh gibson (1996:125) yang menyatakan bahwa seorang manajer efektif mensyaratkan untuk mengenali pribadi individu.

Dari penjelasan di atas, dengan kompetensi yang dimiliki karyawan Koperasi Serba Usaha (KSU) SINAR JAYA di bagian pemasaran yang terdiri atas sikap dan nilai nilai (self concept.) karyawan bagian pemasaran Koperasi Sinar Jaya Malang masih harus dikembangkan lagi. hal itu ditunjukkan kurangnya pengetahuan \begin{tabular}{lccr} 
bersikap ramah & dan & saling \\
menghargai & satu & sama & lain, \\
sopansantun dan & kurang & bisa \\
menempatkan diri & di masyarakat \\
dengan baik. & \multicolumn{2}{c}{ Pengetahuan }
\end{tabular} (knowledge) yang dimiliki karyawan bagian pemasaran sudah baik terbukti dengan cara berkomunikasi yang baik danberwawasan sesuai dengan pengetahuan yang mereka miliki.

Kemampuan (skills) karyawan bagian pemasaran belum dapat dikatakan baik terbukti dengan masih banyak karyawan yang belum bisa memenuhi target perusahaan. Pengetahuan dan Perilaku yang nantinya di jadikan sebagai evaluasi pencapaian tinggi rendahnya prestasi kerja karyawan, dan kompetensi mana yang perlu ditekankan pada diri karyawan bagian sales and marketing yang merupakan bagian yang paling utama dalam perusahaan ini.

\section{TINJAUAN PUSTAKA}

Menurut Spencer and Spencer (1993), kompetensi sebagai karakteristik yang mendasari seseorang dan berkaitan dengan efektifitas kinerja individu dalam pekerjaanya. Berdasarkan definisi tersebut mengandung makna kompetensi adalah bagian kepribadian yang mendalam dan melekat kepada seseorang serta perilaku yang dapat diprediksi pada berbagai keadaan dan tugas pekerjaan.

Analisis kompetensi disusun sebagian besar untuk pengembangan karier, tetapi penentuan tingkat kompetensi dibutuhkan untuk mengetahuiefektivitas tingkat kinerja yang diharapkan. Menurut Spencer (1993) komponen-komponen kompetensi mencakup beberapa hal 
berikut: Motives, Traits, Self concept, Knowledge dan Skill.

Motives adalah sesuatu yang secara konsisten dipikirkan ataudikehendaki seseorang yang menyebabkan tindakan. Traits adalah karakteristik-karakteristik fisik dan respons-respons konsisten terhadap berbagai situasi atau informasi.

Self concept adalah sikap, nilai, dan citra diri seseorang. Knowledge adalah pengetahuan atau informasi seseorang dalam bidang spesifik tertentu. Skill adalah keterampilan/ kemampuan untuk melaksanakan tugas fisik tertentu atau tugas mental tertentu.

Dari komponen-komponen tersebut, keterampilan dan pengetahuansifatnya dapat dilihat (visible) dan mudah dikembangkan dalam programpelatihan dan pengembangan sumber daya manusia, sedangkan citra diri, watak, motif sifatnya tidak tampak (hidden) dan lebih sulit untukdikembangkan melalui program pelatihan dan pengembangan sumber dayamanusia.

Mangkunegara

(2001:67)

mengatakan prestasi kerja adalah hasil kerja secara kualitas, kuantitas dan ketepatan waktu yang dicapai seorang karyawan dalam melaksanakan tugasnya sesuai dengan tanggung jawab yang diberikan kepadanya.

Penilaian pelaksanaan pekerjaan merupakan sebuah pedoman dalam bidang sumberdaya manusia yang diharapkan dapat menunjukkan prestasi kerja karyawan secara rutin dan teratur sehingga dapat bermanfaat bagi pengembangan karir karyawan yang dinilai perusahaan secara keseluruhan.
Disini tampak jelas bahwa pengertian job performance itu lebih sempit sifatnya, yaitu hanya berkenaan dengan apa yang dihasilkan seseorang dari tingkah laku kerjanya. Biasanya orang yang level of performace-nya tinggi disebut sebagai orang yang produktif, dan sebaliknya orang yang levelnya tidak mencapai standar, dikatakan sebagai tidak produktif atau performance rendah.

Berdasarkan pendapat sebelumnya, maka dapat disimpulkan bahwa prestasi kerja adalah sebagai hasil kerja yang telah dicapai seseorang dari tingkah laku kerjanya dalam melaksanakan aktifitas kerja. Informasi tentang tinggi rendahnya prestasi kerja seorang karyawan diperoleh melalui proses yang panjang yaitu proses penilaian prestasi kerja karyawan yang disebut dengan istilah performance appraisal.

Untuk menilai prestasi kerja karyawan pada perusahaan, objek penelitian harus sinkron dengan tujuan penelitian. Apabila tidak sinkron dapat terjadi kekeliruan penelitian tentang prestasi kerja karyawan yang diinginkan.

Kompetensi yang terdiri dari perilaku kunci yang dibutuhkan untuk melaksanakan peran tertentu untuk menghasilkan prestasi kerja yang memuaskan (Ruky, 2003). Perilaku ini ditunjukkan dengan secara konsisten oleh para pekerja yang melakukan aktivitas kerja. Perilaku tanpa maksud dan tujuan tidak bisa didefinisikan sebagai kompetensi.

Hasil penelitian McClelland (Usmara, 2002) hasil penelitian menunjukkan bahwa komptensi yang bersifat non-akademik, seperti 
kemampuan menghasilkan ide-ide yang inovatif, managemen skills, kecepatan mempelajari jaringan kerja, dan sebagainya berhasil memprediksi prestasi individu dalam pekerjaanya.

Penentuan tingkat kompetensi dibutuhkan agar dapat mengetahui tingkat prestasi yang diharapkan untuk kategori baik atau rata-rata. Penentuan kompetensi yang dibutuhkan tentunyan akan dapat dijadikan dasar bagi evaluasi prestasi kerja. Menurut Dharma (2002), kompetensi selalu mengandung maksud dan tujuan, yang merupakan dorongan motif atau trait yang menyebabkan suatu tindakan untuk memperoleh suatu hasil.

\begin{tabular}{|l|}
\hline Kompetensi (X) \\
X1. Kemampuan \\
X2. Pengetahuan \\
X3. Konsep Diri
\end{tabular}$\rightarrow$\begin{tabular}{l}
$\frac{\text { Prestasi Kerja }}{(\mathbf{Y}):}$ \\
Y1. Kualitas \\
Y2. Kuantitas \\
Y3. Ketepatan \\
waktu \\
\hline
\end{tabular}

Gambar 1. Pengaruh Kompetensi Terhadap Prestasi Kerja Karyawan.

\section{Disetiap}

perusahaan

membutuhkan sumber daya manusia yang disebut dengan karyawan. Setiap karyawan dituntut untuk menyelesaikan pekerjaan yang sudah ditentukan. Karyawan dalam menyelesaikan tugas akan menggunakan kompetensi yang mereka miliki, tingkat kompetensi ini sebagai kemampuan individu untuk bekerja secara berkualitas dan efektif dalam bidangnya. Melalui kompetensi tertentu seorang karyawan akan mampu bekerja secara berkualitas, agar tujuan organisasi dapat dicapai secara efisien dan efektif.

\section{METODE PENELITIAN}

Jenis penelitian yang digunakan adalah penelitian survey. Menurut Sugiono (2007:7) survey adalah penelitian yang dilakukan pada populasi besar maupun kecil, tetapi data yang dipelajari adalah data dari sampel yang diambil dari populasi tersebut. Cara pengumpulan data responden dilakukan dengan dua cara wawancara, yaitu kegiatan tanya jawab yang dilakukan terhadap pimpinan Koperasi Serba Usaha (KSU) Sinar Jaya Malang, berdasarkan pada daftar pertanyaan dan data seperti target karyawan, jumlah karyawan.

Kuisioner, kegiatan menyebar daftar pernyataan kepada responden yang berisi item-item variable kompetensi dan prestasi kerja karyawan. Indikator Variabel Prestasi Kerja adalah Kualitas, yaitu kemampuan membuat laporan dengan baik atau memenuhi tujuan yang diharapkan dari pekerjaan tersebut. Kuantitas, adalah Mampu mencapai target yang telah ditentukan oleh perusahaan. Ketepatan waktu, adalah Mampu menarik pinjaman dari nasabah tepat waktu, untuk menghindari terjadinya kredit macet.

Dalam penelitian ini, tanggapan responden diukur dengan menggunakan skala Likert. Dalam Sugiyono (2008:132), dijelaskan bahwa skala Likert digunakan untuk mengukur sikap, pendapat dan persepsi seseorang atau sekelompok orang tentang fenomena sosial.

Dalam penelitian, fenomena sosial ini telah ditetapkan secara spesifik oleh 
peneliti, yang selanjutnya disebut sebagai variabel penelitian. Dengan skala Likert, maka variabel yang akan diukur dijabarkan menjadi indikator variabel. Kemudian indikator tersebut dijadikan sebagai titik tolak untuk menyusun item-item instrumen yang dapat berupa pernyataan atau pertanyaan.

Dalam penelitian ini menggunakan 4 kategori, dan tidak menggunakan 5 kategori karena menurut Nazir (1999:39) skala Likert menggunakan item yang secara pasti baik dan secara pasti buruk, tidak dimasukkan yang agak baik, yang kurang buruk, dan yang netral. Jawaban setiap item instrumen yang menggunakan skala Likert mempunyai gradasi dari sangat negatif sampai sangat positif.

\section{HASIL PENELITIAN DAN PEMBAHASAN}

Berdasarkan Tabel 1 dapat diketahui jenis kelamin responden seluruhnya adalah laki-laki. Karyawan bagian pemasaran Koperasi Serba Usaha (KSU) Sinar Jaya, Malang.sebagian besar adalah laki-laki, hal tersebut dikarenakan banyaknya karyawan bagian lapangan yang secara langsung berhubungan dengan nasabah. Tabel 1 memberikan informasi bahwa jumlah responden terbanyak berusia antara 31 sampai dengan 35 tahun yaitu 10 orang atau 31,3 persen, sedangkan jumlah paling sedikit terdiri atas 6 orang atau 18,8 persen responden berusia antara 36 sampai dengan 40 tahun. Hasil tersebut dapat membuktikan bahwa selama ini perusahaan banyak memperkerjakan karyawan yang sudah mempunyai pengalaman kerja dengan harapan dapat bekerja secara maksimal di perusahaan Dapat diketahui pula bahwa tingkat pendidikan responden terbanyak adalah SMA yaitu sebanyak 15 orang atau 46,9 persen, sedangkan jumlah paling sedikit

Tabel 1. Hasil Kuesioner

\begin{tabular}{lll}
\hline $\begin{array}{c}\text { KARAKTERISTIK } \\
\text { RESPONDEN }\end{array}$ & \multicolumn{1}{c}{ KLASIFIKASI } & HASIL \\
\hline Jenis Kelamin & Laki-laki & 32 orang \\
& Perempuan & 0 orang \\
Usia & 20-25 tahun & 7 orang \\
& $26-30$ tahun & 9 orang \\
& $31-35$ tahun & 10 orang \\
Tingkat Pendidikan & $36-40$ tahun & 6 orang \\
& S1 & 7 orang \\
Status Pernikahan & SMA / SMK & 10 orang \\
& Menikah & 15 orang \\
Masa Kerja & Belum Menikah & 26 orang \\
& $<1$ tahun & 6 orang \\
& $1-2$ tahun & 3 orang \\
& $2-3$ tahun & 5 orang \\
& $3-4$ tahun & 11 orang \\
\end{tabular}

Sumber: Data diolah 2013 
adalah responden dengan tingkat pendidikan S1 yaitu 7 orang atau 21,9 persen dari keseluruhan jumlah responden. Hasil tersebut dapat dikatakan bahwa selama ini pihak menajemen Koperasi Serba Usaha (KSU) Sinar Jaya, Malang menetapkan batas minimal pendidikan formal yang dimiliki para karyawan.

Dalam Tabel 1 juga dapat diketahui jumlah responden terbanyak memiliki status perkawinan sudah menikah yaitu sebanyak 26 orang atau 81,3 persen dan responden yang belum menikah yaitu sebanyak 6 responden atau 18,8 persen. Dengan demikian menunjukkan bahwa sebagian besar karyawan sudah memiliki tanggungan keluarga dari hasil perkawinan yangtelah dilakukan.

Berdasarkan Tabel 1, dapat diuraikan bahwa jumlah responden yang lama bekerjanya $<1$ tahun sebanyak 3 orang atau 9,4\%, responden yang lama bekerjanya 1 tahun- 2 tahun sebanyak 5 orang atau $15,6 \%$ responden yang lama bekerjanya 2 tahun -3 tahun sebanyak 11 orang atau $34,4 \%$. Responden yang lama bekerjanya 3 tahun -4 tahun sebanyak 13 orang atau 40,6\%. Dengan demikian menunjukkan bahwa lama bekerja sebagian besar karyawan bagian pemasaran yaitu $<1$ tahun.

Uji validitas digunakan untuk melihat valid tidaknya masingmasing instrumen dalam variabel kemampuan, pengetahuan, konsep diri dan kinerja karyawan bagian pemasaran Koperasi Serba Usaha (KSU) Sinar Jaya, Malang. Nilai kritik dari pengujian ini adalah 0,000 dengan $\mathrm{DF}=\mathrm{n}-1$ taraf signifikan 0,05 (5\%). Instrumen dikatakan valid jika angka koefisien korelasi yang diperoleh lebih besar dari nilai kritik (r). Adapun hasil uji validitas pada pengujian ini untuk masing-masing variabel adalah sebagai berikut

Tabel 2. Uji Validitas Variabel

\begin{tabular}{|c|c|c|c|c|}
\hline \multicolumn{5}{|c|}{ Kompetensi } \\
\hline Var & Item & $\begin{array}{c}\text { Koefisien } \\
\text { Korelasi }\end{array}$ & $\mathrm{r}_{\text {tabel }}$ & Ket. \\
\hline \multirow[t]{3}{*}{$\mathrm{X} 1$} & (X1.1) & 0.865 & 0.000 & Valid \\
\hline & (X1.2) & 0.870 & 0.000 & Valid \\
\hline & (X1.3) & 0.855 & 0.000 & Valid \\
\hline \multirow[t]{3}{*}{$\mathrm{X} 2$} & (X2.1) & 0.781 & 0.000 & Valid \\
\hline & (X2.2) & 0.867 & 0.000 & Valid \\
\hline & (X2.3) & 0.774 & 0.000 & Valid \\
\hline \multirow[t]{3}{*}{$\mathrm{X} 3$} & (X3.1) & 0.671 & 0.000 & Valid \\
\hline & (X3.2) & 0.936 & 0.000 & Valid \\
\hline & (X3.3) & 0.817 & 0.000 & Valid \\
\hline
\end{tabular}

Sumber: Data diolah 2013

Dari Tabel 2 dapat disimpulkan bahwa semua instrumen variabel kompetensi yang terdiri dari kompetensi kemampuan (X1), kompetensi pengetahuan (X2) dan kompetensi konsep diri (X3) adalah valid, karena terbukti bahwa nilai koefisien lebih besar dari nilai kritik pada tingkat signifikan 5\%.

Tabel 3. Uji Validitas Variabel

\begin{tabular}{ccccc}
\multicolumn{6}{l}{ Prestasi Kerja } \\
\hline Var & Item & $\begin{array}{c}\text { Koefisien } \\
\text { Korelasi }\end{array}$ & $\mathrm{r}_{\text {table }}$ & Ket. \\
\hline $\mathrm{Y}$ & $(\mathrm{Y} 1.1)$ & 0.828 & 0.000 & Valid \\
& $(\mathrm{Y} 1.2)$ & 0.861 & 0.000 & Valid \\
& $(\mathrm{Y} 1.3)$ & 0.837 & 0.000 & Valid \\
\hline
\end{tabular}

Sumber: Data diolah 2013

Dari Tabel 3 dapat disimpulkan bahwa semua instrumen variabel prestasi kerja karyawan adalah valid, karena terbukti bahwa nilai koefisien lebih besar dari nilai kritik pada tingkat signifikan 5\%. 
kritik pada tingkat signifikan 5\%. Nilai koefisien tersebut berkisar antara 0 hingga 1 . Semakin mendekati 1 menunjukkan makin reliabel. Ukuran yang dipakai untuk semakin reliabel bilamana Cronbach'sAlpha di atas 0,6. Adapun hasil uji reliabilitas untuk masing-masing variabel penelitian dapat dilihat pada Tabel 4.

Tabel 4. Hasil Uji Reliabilitas

\begin{tabular}{clcc}
\hline \multicolumn{2}{c}{ Variabel } & $\begin{array}{c}\text { Koefisien } \\
\text { Reliabilitas }\end{array}$ & Ket. \\
\hline $\begin{array}{c}\text { Kompetensi } \\
(\mathrm{X})\end{array}$ & $\begin{array}{l}\text { Kompetensi } \\
\text { Kemampuan } \\
(\mathrm{X} 1)\end{array}$ & 0.852 & Reliabel \\
& $\begin{array}{l}\text { Kompetensi } \\
\text { Pengetahuan } \\
(\mathrm{X} 2)\end{array}$ & 0.865 & Reliabel \\
& $\begin{array}{l} \\
\text { Kompetensi } \\
\text { Konsep Diri } \\
\text { (X3) }\end{array}$ & 0.858 & Reliabel \\
Prestasi & $\begin{array}{l}\text { Stress Kerja } \\
(Y)\end{array}$ & 0.817 & Reliabel \\
Kerja (Y) & & & \\
\hline Sumber: Data diolah 2013 & &
\end{tabular}

Berdasarkan hasil uji reliabilitas dapat disimpulkan bahwa seluruh variabel yang digunakan dalam penelitian ini adalah reliabel, hal tersebut dikarenakan koefisienCronbach's Alpha diatas 0,6. Adapun secara lengkap hasil analisis rentang skala yang dilakukan dan dapat dilihat pada Tabel 5, Tabel 6, Tabel 7, dan Tabel 8.

\begin{tabular}{|c|c|c|c|c|c|c|}
\hline \multirow[b]{2}{*}{ Indikator } & \multicolumn{4}{|c|}{$\begin{array}{c}\text { Jawaban Jumlah } \\
\text { Responden berdasarkan } \\
\text { Skor }\end{array}$} & \multirow[b]{2}{*}{$\begin{array}{l}\text { Total } \\
\text { Skor } \\
\text { Indikator }\end{array}$} & \multirow[b]{2}{*}{$\begin{array}{l}\text { Kriteria } \\
\text { Penilaian }\end{array}$} \\
\hline & $\begin{array}{c}1 \\
\text { Sangat } \\
\text { Tidak } \\
\text { Setuju }\end{array}$ & $\begin{array}{c}2 \\
\text { Tidak } \\
\text { Setuju }\end{array}$ & $\begin{array}{c}3 \\
\text { Setuju }\end{array}$ & $\begin{array}{c} \\
\text { Sangat } \\
\text { Setuju }\end{array}$ & & \\
\hline$(\mathrm{X} 1.1)$ & 0 & 2 & 20 & 10 & 104 & $\begin{array}{l}\text { Sangat } \\
\text { Tinggi }\end{array}$ \\
\hline $\begin{array}{l}(\mathrm{X} 1.2) \\
(\mathrm{X} 1.3)\end{array}$ & $\begin{array}{l}2 \\
0\end{array}$ & $\begin{array}{l}0 \\
3\end{array}$ & $\begin{array}{l}23 \\
23\end{array}$ & $\begin{array}{l}7 \\
6\end{array}$ & $\begin{array}{l}99 \\
99\end{array}$ & $\begin{array}{l}\text { Tinggi } \\
\text { Tinggi }\end{array}$ \\
\hline \multicolumn{5}{|c|}{ Skor Rata-Rata Rentang Skala } & $\begin{array}{c}100.6 \\
7\end{array}$ & Tinggi \\
\hline
\end{tabular}

Dari perhitungan rata-rata rentang skala diperoleh 100.67 yang berarti kompetensi kemampuan terhadap prestasi kerja karyawan dikategorikan tinggi.

Tabel 6. Variabel Kompetensi Pengetahuan (X2)

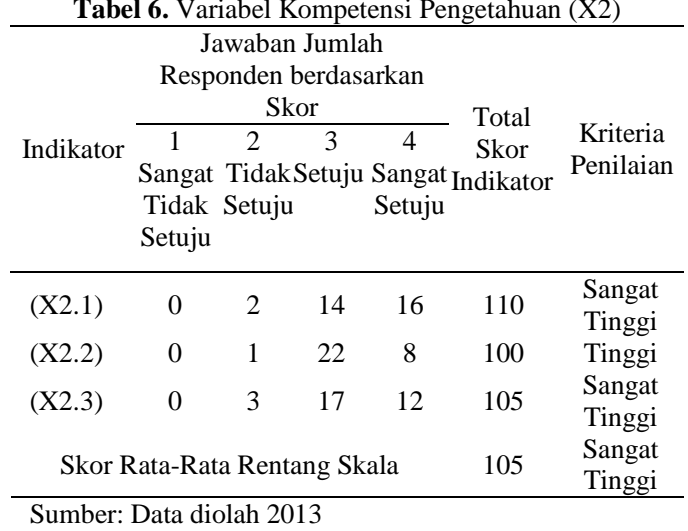

\begin{tabular}{|c|c|c|c|c|c|c|}
\hline \multirow[b]{2}{*}{ Indikator } & \multicolumn{4}{|c|}{$\begin{array}{c}\text { Jawaban Jumlah } \\
\text { Responden berdasarkan } \\
\text { Skor }\end{array}$} & \multirow[b]{2}{*}{$\begin{array}{l}\text { Total } \\
\text { Skor } \\
\text { Indikator }\end{array}$} & \multirow[b]{2}{*}{$\begin{array}{l}\text { Kriteria } \\
\text { Penilaian }\end{array}$} \\
\hline & $\begin{array}{l}1 \\
\text { Sangat } T \\
\text { Tidak S } \\
\text { Setuju }\end{array}$ & $\begin{array}{l}2 \\
\text { Cidak } \\
\text { etuju }\end{array}$ & $\begin{array}{c}3 \\
\text { Setuju }\end{array}$ & $\begin{array}{c}4 \\
\text { Sangat } \\
\text { Setuju }\end{array}$ & & \\
\hline$(\mathrm{X} 3.1)$ & 0 & 1 & 12 & 19 & 114 & $\begin{array}{l}\text { Sangat } \\
\text { Tinggi }\end{array}$ \\
\hline$(\mathrm{X} 3.2)$ & 1 & 0 & 17 & 14 & 108 & $\begin{array}{l}\text { Sangat } \\
\text { Tinggi }\end{array}$ \\
\hline$(\mathrm{X} 3.3)$ & 0 & 1 & 19 & 12 & 107 & $\begin{array}{l}\text { Sangat } \\
\text { Tinggi }\end{array}$ \\
\hline \multicolumn{5}{|c|}{ Skor Rata-Rata Rentang Skala } & $\begin{array}{c}109.6 \\
7\end{array}$ & $\begin{array}{l}\text { Sangat } \\
\text { Tinggi }\end{array}$ \\
\hline
\end{tabular}

Sumber: Data diolah 2013

Tabel 8. Variabel Prestasi Kerja (Y) Jawaban Jumlah Responden berdasarkan

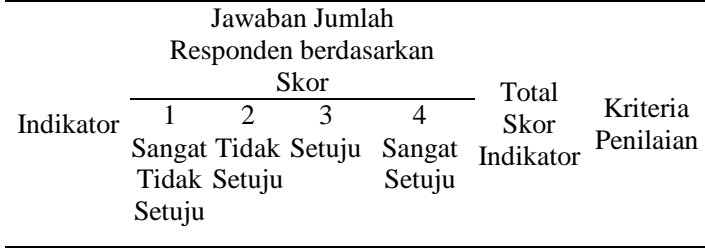

\begin{tabular}{lllllll}
\hline (Y1.1) & 0 & 6 & 22 & 4 & 94 & Tinggi \\
(Y1.2) & 0 & 8 & 20 & 4 & 92 & Tinggi \\
(Y1.3) & 0 & 5 & 24 & 3 & 94 & Tinggi \\
Skor Rata-Rata Rentang Skala & 93.33 & Tinggi \\
\hline
\end{tabular}

Sumber: Data diolah 2013

Berdasarkan perhitungan ratarata rentang skala pada Tabel 8 diperoleh 93.33 yang berarti prestasi kerja karyawan dikategorikan tinggi. 
Selanjutnya dilakukan analisis mengenai pengaruh kompetensi terhadap prestasi kerja karyawan Koperasi Sinar Jaya Malang.Analisis data dilakukkan dengan metode regresi linier berganda. Hasil dapat diketahui pada Tabel 9.

Tabel 9. Hasil Analisis Regresi Linear Berganda Variabel B Beta thitung Sig t Ket.

Konstanta 4.099

$\begin{array}{lllll}(X 1.1) & 0.490 & 0.353 & 4.438 & 0.000 \text { Signifikan }\end{array}$ $\begin{array}{lllll}(X 1.2) & 0.576 & 0.618 & 5.143 & 0.000 \text { Signifikan }\end{array}$ $\begin{array}{lllll}(X 1.3) & 0.247 & 0.525 & 2.150 & 0.000 \text { Signifikan }\end{array}$ Sumber: Data diolah 2013

Hasil perhitungan determinasi menunjukkan besarnya sumbangan variabel kemampuan (X1), pengetahuan (X2), konsep diri (X3), variabel prestasi kerja karyawan (Y). Berdasarkan Tabel 4.15 didapatkan persamaan regresi sebagai berikut $: Y$ $=4,099+0,490 \mathrm{X} 1+0,576 \quad \mathrm{X} 2+$ $0,247 \mathrm{X} 3+\mathrm{e}$

Dari hasil analisis regresi linear berganda diatas maka didapatkan hasil $\mathrm{F}$ hitung sebesar 17,001 dengan tingkat signifikan 0,000 . Untuk melakukan pengujian apakah variabel independent secara simultan (bersama-sama) mempunyai pengaruh terhadap variabel dependent atau tidak berpengaruh maka digunakan uji $\mathrm{F}$ yaitu dengan cara membandingkan $F_{\text {hitung }}$ dengan $\mathrm{F}_{\text {tabel }}$ pada taraf nyata $\alpha=0,05$. Dari hasil analisis regresi berganda maka diperoleh $F_{\text {tabel }}$ sebesar 2,955 sedangkan $F_{\text {hitungnya }}$ diperoleh sebesar 17,001sehingga dari perhitungan diatas dapat diketahui hipotesis yang diajukan terbukti diterima. Dengan demikian dapat disimpulkan bahwa kompetensi yang terdiri dari kompetensikemampuan, pengetahuan, dan konsep diri berpengaruh signifikan terhadap prestasi kerja karyawan Koperasi Sinar Jaya Malang.

Berdasarkan hasil analisis regresi diperoleh $\mathrm{t}$ hitung untuk variabel kompetensi kemampuan sebesar 4,438. Kemudian $t$ tabel $(\alpha=$ $0.05)$ adalah sebesar 2,042. Karena t hitung > t tabel yaitu 4,438>2,055 maka dapat diketahui bahwa pengaruh kompetensi kemampuan (X1) dengan prestasi kerja (Y) adalah signifikan. Hal ini berarti $\mathrm{H}_{\mathrm{o}}$ ditolak dan $\mathrm{H}_{\mathrm{a}}$ diterima sehingga dapat disimpulkan bahwa prestasi kerja karyawan Koperasi Sinar Jaya Malang dapat dipengaruhi secara signifikan oleh kompetensi kemampuan.

Kemudian hasil analisis regresi diperoleh $\mathrm{t}$ hitung untuk variabel kompetensi pengetahuan sebesar 5,143. Sedangkan t tabel ( $\alpha$ $=0.05)$ adalah sebesar 2,042. Karena $\mathrm{t}$ hitung $<\mathrm{t}$ tabel yaitu $5,143<2,055$ maka dapat diketahui bahwa pengaruh kompetensi pengetahuan (X2) dengan prestasi kerja (Y) adalah signifikan. Hal ini berarti $\mathrm{H}_{\mathrm{o}}$ ditolak dan $\mathrm{H}_{\mathrm{a}}$ diterima sehingga dapat disimpulkan bahwa prestasi kerja karyawan Koperasi Sinar JayaMalangdapat dipengaruhi secara signifikan oleh kompetensi pengetahuan.

Selanjutnya hasil analisis regresi diperoleh $t$ hitung untuk variabel kompetensi konsep dirisebesar 2,150 Sedangkan $t$ tabel $(\alpha$ $=0.05$ ) adalah sebesar 2,042. Karena $\mathrm{t}$ hitung $<\mathrm{t}$ tabel yaitu 2,150< 2,042 maka dapat diketahui bahwa pengaruh kompetensi konsep diri (X3) dengan prestasi kerja (Y) adalah signifikan. Hal ini berarti $\mathrm{H}_{\mathrm{o}}$ ditolak dan $\mathrm{H}_{\mathrm{a}}$ diterima sehingga dapat 
disimpulkan bahwa prestasi kerja karyawan Koperasi Sinar Jaya Malang dipengaruhi secara signifikan oleh kompetensi konsep diri.

\section{HASIL PENELITIAN DAN PEMBAHASAN}

Berdasarkan data yang diperoleh dapat diketahui bahwa terdapat pengaruh antara kompetensi kemampuan (X1), kompetensi pengetahuan (X2), dan kompetensi konsep diri (X3) terhadap prestasi kerja (Y) pada Koperasi Sinar Jaya Malang dengan kompetensi pengetahuan (X2) adalah variabel yang paling berpengaruh. Hal ini bisa ditunjukkan dari hasil analisis regresi linear berganda pada tabel 4.16 yang menunjukkan nilai standar koefisien kompetensi pengetahuan (X2) lebih besar dari pada nilai standar koefisien kompetensi kemampuan (X1) dan nilai standar koefisien kompetensi konsep diri (X3).

Selain itu, hal yang menunjukkan bahwa kompetensi pengetahuan (X2) lebih dominan daripada kompetensi kemampuan (X1) dan kompetensi konsep diri (X3) adalah dari nilai t hitung. Dari ketiga kompetensi tersebut, nilai $\mathrm{t}$ hitung kompetensi pengetahuan lebih besar daripada nilai $\mathrm{t}$ hitung kompetensi kemampuan dan nilai $t$ hitung kompetensi konsep diri dengan jumlah t hitung sebesar 5,143.

Hasil penelitian ini juga menjawab dugaan sementara/ hipotesis peneliti yang dicantumkan sebelumnya. Adapun hipotesis yang dicantumkan sebelumnya menjelaskan bahwa diduga kompetensi memiliki pengaruh terhadap prestasi kerja karyawan di Koperasi Sinar Jaya
Malang.Hipotesis kedua yang dicantumkan menjelaskan bahwa diduga kompetensi pengatahuan memiliki pengaruh yang paling signifikan diantara kompetensi lainnya.

\section{SIMPULAN}

Berdasarkan hasil penelitian dan pembahasan dapat ditarik kesimpulan sebagai berikut: kompetensi karyawan bagian Pemasaran yang terdiri dari kompetensi kemampuan masuk dalam kategori tinggi, sedangkan kompetensi pengetahuan dan konsep diri masuk dalam kategori sangat tinggi pada Koperasi Serba Usaha (KSU) Sinar Jaya Malang,

Gambaran prestasi kerja karyawan bagian Pemasaran Koperasi Serba Usaha (KSU) Sinar Jaya Malang, masuk dalam kategori tinggi. Terdapat pengaruh antara variable kompetensi kemampuan, kompetensi pengetahuan dan kompetensi konsep diri terhadap prestasi kerja karyawan Pemasaran Koperasi Serba Usaha (KSU) Sinar Jaya Malang, Variabel kompetensi Pengetahuan yang paling berpengaruh terhadap prestasi kerja karyawan karyawan bagian Pemasaran Koperasi Serba Usaha (KSU) Sinar Jaya Malang.

Berdasarkan hasil kesimpulan dari hasil penelitian, maka diajukan beberapa saran. Untuk mencapai hasil yang baik, penulis memberikan saran berdasarkan jawaban responden pada rentang skala kompetensi kemampuan dimana masih terdapat beberapa responden yang menjawab tidak setuju dan sangat tidak setuju, yang berarti bahwa beberapa responden masih belum memiliki 
kompetensi kemampuan dengan baik. Melihat kondisi tersebut perusahaan perusahaan hendaknya berupaya meningkatkan kompetensi para karyawan melalui pelatihan dan pengembangan serta penilaian prestasi kerja karyawan.

Mengingat kompetensi yang baik merupakan hal yang memberikan pengaruh yang penting terhadap prestasi kerja karyawan, diharapkan hasil penelitian ini dapat dipakai sebagai acuan bagi peneliti lain untuk menggunakan variabel lain yang berpengaruh terhadap prestasi kerja karyawan, yang meliputi: motivasi, pelatihan, gaya kepemimpinan, atau mengadakan penelitian mengenai faktor-faktor lain yang juga mempunyai pengaruh besar terhadap prestasi kerja karyawan.

\section{DAFTAR PUSTAKA}

Agustin. Wiwin, 2009, Pengaruh Kompetensi Sumberdaya Manusia terhadap Kinerja Karyawan Universitas Bina Dharma. Skripsi Sarjana Universitas Muhammadiyah, Malang.

Arikunto. 2006. Prosedur Penelitian Suatu Pendekatan Praktek.EdisiRevisi V. Penerbit Rineka Cipta: Jakarta.

Dharma, A. 1985. Manajemen Prestasi Kerja. Jakarta: Rajaali Pers.

Gitosudormo, Indriyo dan Nyoman Sudita. 2000. Perilaku Keorganisasiaan. Cetakan Pertama, yogyakarta : PT. Rineka Cipta.

Gibson. 1996. Organisasi dan manajemen : perilaku, struktur, dan proses. Erlangga, jakarta

Handoko, Hani, 2001. Manajemen Personalia Sumber Daya Manusia, Edisi pertama, Penerbit BPFE, Yogyakarta

Hasibuan, malayu SP. 2007. Manajemen Sumber Daya Manusia. Jakarta : Bumi Aksara

Hariandja, Marihot Tua Effendi. 2002. Manajeman Sumber Daya Manusia. Cetakan Pertama. Jakarta : PT. Gramedia Widia Sarana Indonesia .

Mangkunegara, Anwar Prabu. 2005. Perilaku dan Budaya Organisasi. Cetakan Pertama. Bandung : PI Refika Aditama Mardany.Yuanna, 2008, Pengaruh Kompetensi terhadap Kinerja Karyawan bagian Sales and Marketing hotel Tretes Raya Prigen Pasuruan. Skripsi Sarjana Universitas Muhammadiyah, Malang.

Rao, T.V. 1992. Penilaian Prestasi Kerja: Teori dan Praktek. Jakarta Pustaka

Robins, Stephen. P. 2003. Perilaku Organisasi. Jilit II. Jakarta : PT. Indeks Kelompok Gramedia

Robert Kreitner, Angelo Kinichi.2005. Perilaku Organisasi Edisi ke 5 Jilid 2. Salemba Empat: Jakarta.

Sigit, soehardi,Prof., Dr., 2001. Pengantar metodologi penelitian Sosial-BisnisManajemen ; Edisi Kedua, BPFE, Yogyakarta.

Sugiono. 1992. Metode Penelitian Bisnis. CV. Alfa Beta, Bandung. 
Sutrisno, Edy H. DR., Msi., 2010. Manajemen Sumber Daya Manusia.Edisi ke 1 cetakan ke 2. Kencana: Jakarta.
Umar, Husein. 2003. Metode riset prilakuorganisasi.

Gramedia Pustaka utama, Jakarta 